\title{
Onto the Farm, into the Home: How Intrahousehold Gender Dynamics Shape Land Restoration in Eastern Kenya ${ }^{\mathrm{a}}$
}

\author{
Mary Crossland, Ana Maria Paez Valencia, Tim Pagella, Christine Magaju, Esther Kiura, \\ Leigh Winowiecki and Fergus Sinclair
}

\begin{abstract}
While attention has been paid largely to forest restoration, meeting global land restoration pledges will require scalingup restoration of ecosystem services on agricultural land. This paper contributes to the literature on restoration practice and agricultural technology adoption, by shifting the focus onto the farm and considering the role of intrahousehold dynamics in the uptake of farmland restoration practices. We examine the intrahousehold decisions and gender relations surrounding the trial of two on-farm restoration practices: tree planting and planting basins; with over 2,500 farmers in the eastern drylands of Kenya. Combining results from household surveys, interviews and focus group discussions, our findings reveal that decisions over the uptake of restoration practices, although usually initiated by women who attend agricultural workshops, are often discussed between husband and wife and that multiple social dimensions intersect to shape men's and women's interest in, contribution to, and benefit from different practices. Furthermore, our study demonstrates that these intrahousehold relations are, in turn, shaped by women's participation in innovation processes and broader societal changes, particularly the outmigration of rural men. Based on these insights, we offer recommendations for improving the dissemination and uptake of on-farm restoration practices in eastern Kenya and achieving more inclusive and gender-equitable outcomes.
\end{abstract}

Keywords: decision-making, labor, smallholder agriculture, technology adoption, women's agency

\section{\$)) Restoration Recap (\%}

- Meeting restoration targets requires scaling-up restoration on agricultural land as well as forest and therefore the widespread adoption of restorative farming practices by smallholder farm households.

- Decisions over the use of restorative farming practices, although initiated by individuals who attend agricultural workshops, are often discussed between husband and wife, with men's and women's involvement in uptake decisions strongly related to their labor contributions in implementing innovations.
- Employing an intrahousehold approach to on-farm restoration is likely to increase both the uptake of restoration practices and the success and equity of on-farm restoration efforts.

- Such actions begin with gender analysis of intervention options and may include: encouraging couples to attend training events; providing guidance on intrahousehold decision-making and negotiation; facilitating discussion of gender roles; and using participatory planned comparisons that allow households to test and compare options and variations of them.
2 This open access article is distributed under the terms of the CC-BYNC-ND license (http://creativecommons.org/licenses/by-nc-nd/3.0) and is freely available online at: http://er.uwpress.org

Ecological Restoration Vol. 39, Nos. 1-2, 2021

ISSN 1522-4740 E-ISSN 1543-4079

(O2021 by the Board of Regents of the University of Wisconsin System.
T and restoration and avoiding further degradation is seen as a critical pathway to achieving multiple global objectives, from improving food security and ending poverty, to mitigating climate change and conserving biodiversity (Cowie et al. 2018, IPBES 2018). As a result, the past decade has seen an unprecedented commitment to restoring deforested and degraded land. Under initiatives such as the Bonn Challenge and the UN Sustainable 
Development Goals, governments across the globe have pledged to restore hundreds of millions of hectares of degraded land by 2030, while the UN recently declared 2021-2030 the "Decade on Ecosystem Restoration".

More than two billion hectares of land are estimated to offer opportunities for restoration worldwide, and a large proportion are located in sub-Saharan Africa (SSA), on or adjacent to agricultural lands (Minnemeyer et al. 2011). Meeting national restoration commitments therefore depends on the cumulative effect of management decisions made by smallholder farmers to adopt restorative farming practices-defined here as farming activities that aim to avoid, reduce or reverse degradation processes and increase ecosystem service provision.

In the eastern drylands of Kenya, a major driver of land degradation is the use of unsustainable agricultural practices (Tiffen et al. 1994). For example, practices that do not replenish soil nutrients and that lead to soil erosion, including inappropriate land preparation, removal of crop residues and limited use of organic inputs such as farmyard manure. As a result, cultivated lands are often characterized by nutrient-depleted, crusted soils, low in organic carbon and prone to erosion and compaction (Gitau et al. 2006, Rockström et al. 2009).

Increasing tree cover on farms is often considered a key approach to dryland restoration. This is due to the multiple ecological and socio-economic benefits trees provide including enhanced soil fertility, erosion control, improved water cycling, carbon sequestration and the provision of tree products such as timber, medicine and food (Brancalion et al. 2019, Lohbeck et al. 2020). Consequently, Kenya has set a target of maintaining over $10 \%$ tree cover by 2022, which includes agricultural lands (MEF 2019).

Another promising dryland restoration practice is the use of planting basins, a soil and water conservation technique where small pits are dug, usually in a grid formation, filled with farmyard manure and crops planted within them. These basins reduce surface run-off and soil erosion, increase infiltration by breaking through soil crusts and hardpans, and improve soil fertility and water availability, helping to bridge intra-seasonal dry spells and increase crop yields under arid conditions (Mazvimavi and Twomlow 2009, Muli et al. 2017).

While promising restorative farming practices such as tree planting and planting basins exist for drylands, reaching large numbers of farmers and changing current farming practices will require an understanding of which restoration options best suit different farming and farmer circumstances and the potential barriers to their adoption (Coe et al. 2014). On-farm restoration practices such as tree planting and planting basins are also likely to have strong gender-dimensions to their uptake and use. Common barriers to the adoption of agricultural innovations by smallholder farmers, and in particular women, include a lack of access to resources such as land, water and labor; capital and credit constraints; inadequate extension services, and limited market access (Meinzen-Dick et al. 2012, Ragasa et al. 2014, Magruder 2018). While most adoption studies consider the influence of these impediments at the household level and the disparities between male- and femaleheaded households, less attention has been paid to the role of intrahousehold dynamics-the relations between men and women within the same household that influence the division of labor and the use, control and ownership of household resources (Doss and Morris 2001, Doss 2013, Haider et al. 2018).

Many adoption studies still frame technological change in terms of the economic rationality of individual choices, but there is growing recognition that innovation (the widespread adoption of change) is shaped by social relations and negotiations amongst actors, including those living within the same household (Glover et al. 2019, Badstue et al. 2020, Farnworth et al. 2020). In households with multiple decision-makers, changes made to farming activities and practices (innovations), are often negotiated between multiple members, each with differing preferences, priorities and bargaining power (Theis et al. 2018, Shibata et al. 2020). Even when men and women within the same household manage separate plots of land, decisions over the allocation of household labor and resources may be negotiated at the household level (Doss and Meinzen-Dick 2015, Doss and Quisumbing 2020). Restoration initiatives that target individual farmers without considering their whole household and all of those involved in decisions over the use of an innovation (uptake decisions) may be less effective than those that do.

Intrahousehold bargaining power is strongly associated with ownership and control of assets and resources, such as land (Deere and Doss 2006, Meinzen-Dick et al. 2011). In Kenya, despite the national constitution granting men and women equal rights to inherit and own land, women's land rights remain restricted by customary norms, with women typically attaining secondary use rights through their husbands rather than inheritance (Musangi 2017). As a result, men typically exercise greater control over decisions regarding agricultural activities, particularly those involving more permanent, long-term investments such as tree planting (Kiptot and Franzel 2012).

In addition to considering who is involved in uptake decisions over restorative farming practices, it will also be essential to consider whose labor will be used or saved by their adoption. Changes in farming practice can alter the amount of labor required and the timing of associated activities and who is responsible for these tasks (Njuki et al. 2014, Theis et al. 2018). Rural women are often primarily responsible for much of the work within the home; innovations that require additional labor risk increasing their already heavy workloads (Doss 2001, Njuki et al. 2016). Since on-farm restoration practices are typically laborintensive (e.g., planting trees, constructing soil and water 
Table 1. Tree species distributed by the project (Magaju et al. 2020), their uses and environmental and socio-economic benefits (Orwa et al. 2009).

\begin{tabular}{llc}
\hline Tree Species & Uses and Benefits & Total Seedlings Planted \\
\hline Mangifera indica (mango) & Fruit, apiculture, timber, firewood, charcoal, shade/shelter, & 15,226 \\
& tannin/dyes, medicine, soil improvement: mulch & 7,330 \\
Melia volkensii (melia) & Timber, apiculture, livestock fodder, pesticide & 5,618 \\
Azadirachta indica (neem) & Erosion control, medicine, pesticide, timber, fruits, charcoal, & \\
shade/shelter, tannin/dyes & 3,905 \\
Senna siamea (Siamese senna) & Livestock fodder, erosion control, firewood, charcoal, timber, & \\
Moringa oleifera (moringa) & soil improvement: mulch, medicine, shade/shelter, tannin/dyes & 1,702 \\
& Vegetable/oil, erosion control, livestock fodder, apiculture, \\
Carica papaya (pawpaw) & fibre, tannin/dyes, medicine, soil improvement: mulch & 1,068 \\
Calliandra calothyrsus (Calliandra) & Fruit, medicine & 348 \\
& Livestock fodder, erosion control, apiculture, firewood, fibre, & shade/shelter, soil improvement: nitrogen fixing and mulch \\
\hline
\end{tabular}

conservation structures, fencing exclosures), the extent to which associated labor changes benefit or disadvantage men and women requires careful consideration. For example, in Southern Africa, the uptake of planting basins has been reported to shift the burden of land preparation from men to women (Baudron et al. 2007, Nyanga et al. 2012).

In this paper, we contribute to both the literature on restoration practice and agricultural technology adoption more broadly, by shifting the restoration focus onto the farm and considering the role of intrahousehold dynamics in the initial uptake and adaptation of two on-farm restoration practices: tree planting and planting basins; with over 2,500 farmers in eastern Kenya. Specifically, we ask: how do intrahousehold decision-making dynamics and gender relations influence the uptake of restorative farming practices? And, in turn, how do these restorative practices and how they are disseminated, influence gender relations and divisions of labor within the household? Through answering these questions, we identify key entry points for improving the dissemination of on-farm restoration practices in the eastern drylands of Kenya and offer recommendations for achieving more inclusive and gender-equitable restoration outcomes.

\section{Methods}

This research was embedded in a dryland restoration project working with over 2,500 smallholder farmers in eastern Kenya (World Agroforestry 2020). The project sought to improve the livelihoods and food security of smallholder farm households through supporting local innovation and encouraging farmers to systematically test and adapt restoration practices that they were interested in (Coe et al. 2014). This involved planned comparisons (PCs), where farmers choose and compare the performance of different options and corresponding variations thereof, in their own terms, on their own farms (Coe et al. 2017). Researchers and development partners then work with farmers to monitor the performance of each option across a range of social and ecological contexts to develop an evidence base for identifying which options work best where and for whom (Sinclair and Coe 2019).

Over a five-year period, the project worked with farmers to conduct PCs involving two restorative farming practices: tree planting and planting basins. A significant barrier to increasing tree cover, particularly in the drylands, is low seedling survival caused by erratic climate, inappropriate management practices and use of ecologically unsuitable species (De Leeuw et al. 2014, Ndegwa et al. 2017, Derero et al. 2020). The project worked with farmers to compare the effect of different planting and management practices on tree seedling survival, including planting hole size, planting with or without manure and different watering regimes (Magaju et al. 2020). Seven drought-tolerant, multipurpose tree species, many of which provide both ecological and socio-economic benefits, were selected through consultative workshops with farmers (Table 1).

The second planned comparison involved planting basins. While basins have long been promoted in arid areas of SSA, including Kenya, questions remain regarding the most appropriate size of basin and soil treatment for different farming contexts (Danjuma and Mohammed 2015). Farmers compared Zea mays (maize) yield in different basin sizes and manure treatments against their usual cultivation practices of ox plough or hand hoe cultivation. This study focused on the intrahousehold dynamics and gender relations associated with farmers' involvement in these PCs and their implementation of the practices.

\section{Study sites}

The study was conducted across six sub-counties in Machakos, Makueni, and Kitui counties in eastern Kenya (Figure 1). This semi-arid region is characterized by small-scale, rain-fed agriculture subject to frequent drought and crop failures caused by increasingly unreliable rainfall (KNBS 2019). Agricultural productivity is limited by extensive land degradation and many rural households experience food insecurity (KFSSG 2019). The sites were selected to cover 


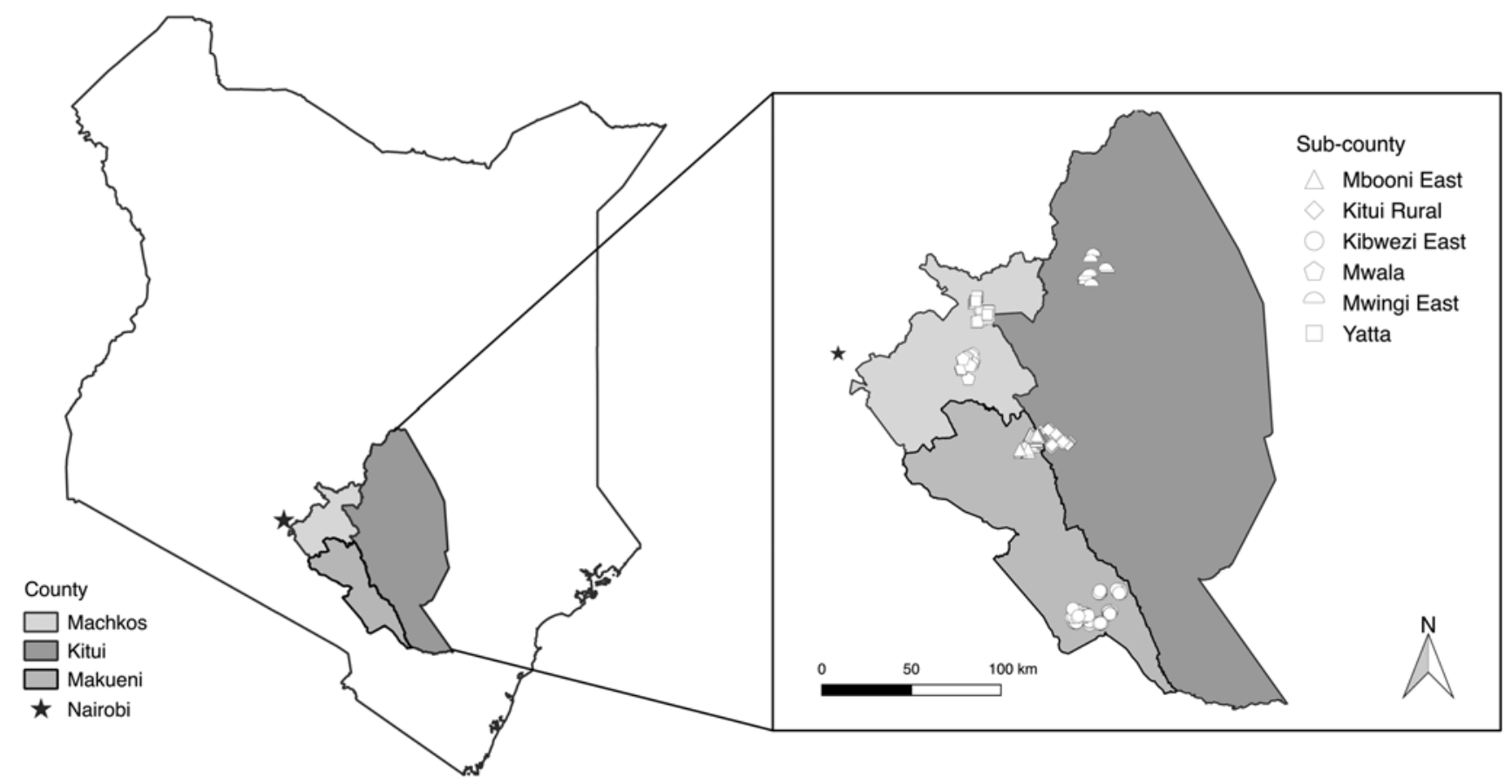

Figure 1. Map of study sites and survey locations in Machakos, Makueni and Kitui counties in eastern Kenya.

a range of socio-ecological conditions and vary in average annual precipitation and temperature (Table 2) and their proximity to urban centres (Figure 1), influencing their connectivity to markets, off-farm employment opportunities and agricultural potential.

\section{Data Collection and Analysis}

In 2018, structured surveys were conducted with 1,293 and 511 farmers across the six sites to monitor the tree planting and basin PCs, respectively (Table 3). These surveys included questions detailing who was involved with decision-making and implementation. A household survey was also used to collect basic socioeconomic data on each farmer and their household (Winowiecki et al. 2019). All surveys were administered using Open Data Kit Collect installed on smart-phones (Hartung et al. 2010) and by trained enumerators who spoke the local language (Kamba). Descriptive analysis of survey data was conducted in R software version 3.6.3 (R Core Team 2020).

We conducted interviews with 62 farmers and conducted 12 sex-segregated focus group discussions (FGDs) to explore patterns arising from the surveys (Table 3). Key areas of inquiry included: how decisions over the PCs and agricultural innovations, in general, are made; women's agency-specifically, their ability to influence uptake decisions (Kabeer 1999); gender-related roles and norms surrounding farming activities and divisions of labor within the household; and the benefits and challenges associated with tree planting and basins.

FGDs included the use of vignettes (short stories) to explore community-level trends in decision-making. This involved reading to participants vignettes depicting different levels of consultation over the uptake of agricultural innovations. These vignettes were developed to cover a range of decision-making dynamics and included the various types of consultation identified from interviews. Each participant was asked to vote, in private, on which male and female vignette best described how men and women within their community typically make uptake decisions. Voting results then formed the basis for further discussion around men's and women's involvement in uptake decisions, including participants' reasons for choosing

Table 2. Climatic information for study sites. Statistics presents: mean (SD) annual precipitation (Funk et al. 2015) and annual temperature (Sparks 2018).

\begin{tabular}{lcccccc}
\hline & \multicolumn{2}{c}{ Machakos County } & \multicolumn{2}{c}{ Makueni County } & \multicolumn{2}{c}{ Kitui County } \\
\cline { 2 - 6 } & Mwala & Yatta & Kibwezi East & Mbooni East & Waita & Lower Yatta \\
\hline Annual average & 866.6 & 710.9 & 609.9 & 689.7 & 768.3 & 617.9 \\
precipitation (mm) & $(198.4)$ & $(189.0)$ & $(166.9)$ & $(187.0)$ & $(220.2)$ & $(163.6)$ \\
Annual average & 21.2 & 23.0 & 25.2 & 23.1 & 25.4 & 23.1 \\
temperature $\left(\mathrm{C}^{\circ}\right)$ & & & & & & \\
\hline
\end{tabular}


Table 3. Gender of study participants involved in the surveys, interviews and focus group discussions in each site.

\begin{tabular}{|c|c|c|c|c|c|c|c|}
\hline & \multicolumn{2}{|c|}{ Machakos } & \multicolumn{2}{|c|}{ Makueni } & \multicolumn{2}{|c|}{ Kitui } & \multirow[b]{2}{*}{$\begin{array}{c}\text { Total } \\
(\mathrm{n}=1973)\end{array}$} \\
\hline & $\begin{array}{c}\text { Mwala } \\
(n=145)\end{array}$ & $\begin{array}{c}\text { Yatta } \\
(n=357)\end{array}$ & $\begin{array}{l}\text { Kibwezi East } \\
(n=322)\end{array}$ & $\begin{array}{l}\text { Mbooni East } \\
(\mathrm{n}=189)\end{array}$ & $\begin{array}{l}\text { Mwingi East } \\
\quad(n=582)\end{array}$ & $\begin{array}{l}\text { Kitui Rural } \\
(n=378)\end{array}$ & \\
\hline \multicolumn{8}{|c|}{ Planting basin survey } \\
\hline Men & 14 & 7 & 25 & 13 & 20 & 24 & 103 \\
\hline Women & 26 & 34 & 65 & 62 & 73 & 148 & 408 \\
\hline \multicolumn{8}{|c|}{ Tree planting survey } \\
\hline Men & 33 & 53 & 34 & 44 & 203 & 62 & 429 \\
\hline Women & 45 & 238 & 158 & 47 & 260 & 116 & 864 \\
\hline \multicolumn{8}{|c|}{ Individual interviews } \\
\hline Men & 2 & 4 & 4 & 3 & 3 & 3 & 19 \\
\hline Female & 8 & 7 & 7 & 8 & 6 & 7 & 43 \\
\hline \multicolumn{8}{|c|}{ Focus group participants } \\
\hline Men & 5 & 6 & 7 & 5 & 9 & 9 & 41 \\
\hline Female & 12 & 8 & 22 & 7 & 8 & 9 & 66 \\
\hline
\end{tabular}

a particular vignette and their perceptions on spousal disagreement and negotiation regarding uptake decisions.

For the interviews and FGDs, stratified random sampling was used to ensure the representation of men and women involved in the two PCs. However, our resulting sample shows a bias towards women since men were often engaged in off-farm activities and were unavailable to participate. For the interviews, questions were translated into Kamba and piloted with eight farmers. All interviews were audio-recorded and transcribed into English. Following data collection, qualitative analysis was performed using NVivo 11 software (NVivo 11, QSR International, Doncaster, Australia). Textual data from interview transcripts and notes from FGDs were deductively coded for content analysis using a coding tree developed from the interview and FGD facilitation guides. Additional codes were later inductively developed based on dominant topics raised by participants.

\section{Results}

\section{Farmer and Household Characteristics}

The majority of farmers involved in the PCs were married, aged between 36-55 and female (Table 4). However, a higher percentage of men were involved in the tree planting PC than the basin PC. We also saw several differences in farmer characteristics across sites. A higher percentage of participants in Mwala saw farming as their primary source of income, were more food secure and male. This likely reflects Mwala's better connection to urban markets and more favourable farming conditions, resulting in men being more interested in investing in agricultural innovations. Similarly, 49\% of Makueni participants reported having a secondary source of income from off-farm activities, compared to only 35\% and 22\% in Kitui and Machakos counties, respectively. This likely reflects the high rates of male outmigration and off-farm employment found in Makueni County (Crossland et al. 2021). Households in Kitui were also less well-off than in Machakos and Makueni counties, in that they were more dependent on food aid, less connected and live in less permanent housing.

\section{Household's Decision to Take Part in the Planned Comparisons}

Our survey indicated that the household's decision to participate in the PCs was most often made by men and women respondents independently, although sometimes jointly with their spouse (Table 5) - a trend reflected in our interviews, with $63 \%$ and $69 \%$ of men and women having self-decided over the PCs, respectively. However, surveyed men's and women's involvement in this decision varied with restoration practice and respondent's gender and marital status, likely reflecting differences in labor requirement and the gender-related roles and norms surrounding tree tenure and outputs from innovations. For married respondents, more men than women reported that their spouse alone had decided to be involved in the basin PC, possibly reflecting that basins are mainly used to grow maize for household consumption-a predominantly female responsibility. For tree planting, there were fewer joint decisions and more men than women made the decision alone, likely reflecting local customary norms surrounding tree tenure, with tree planting and felling traditionally a male domain (Kiptot and Franzel 2012). Greater joint decision-making over the basin PC compared to the tree planting PC could also reflect that, compared to tree planting, digging basins involved substantial labor contributions from other household members (Figure 2). Nevertheless, it should be noted that disparities in men's and women's answers may also be because men are systematically less likely than women to 


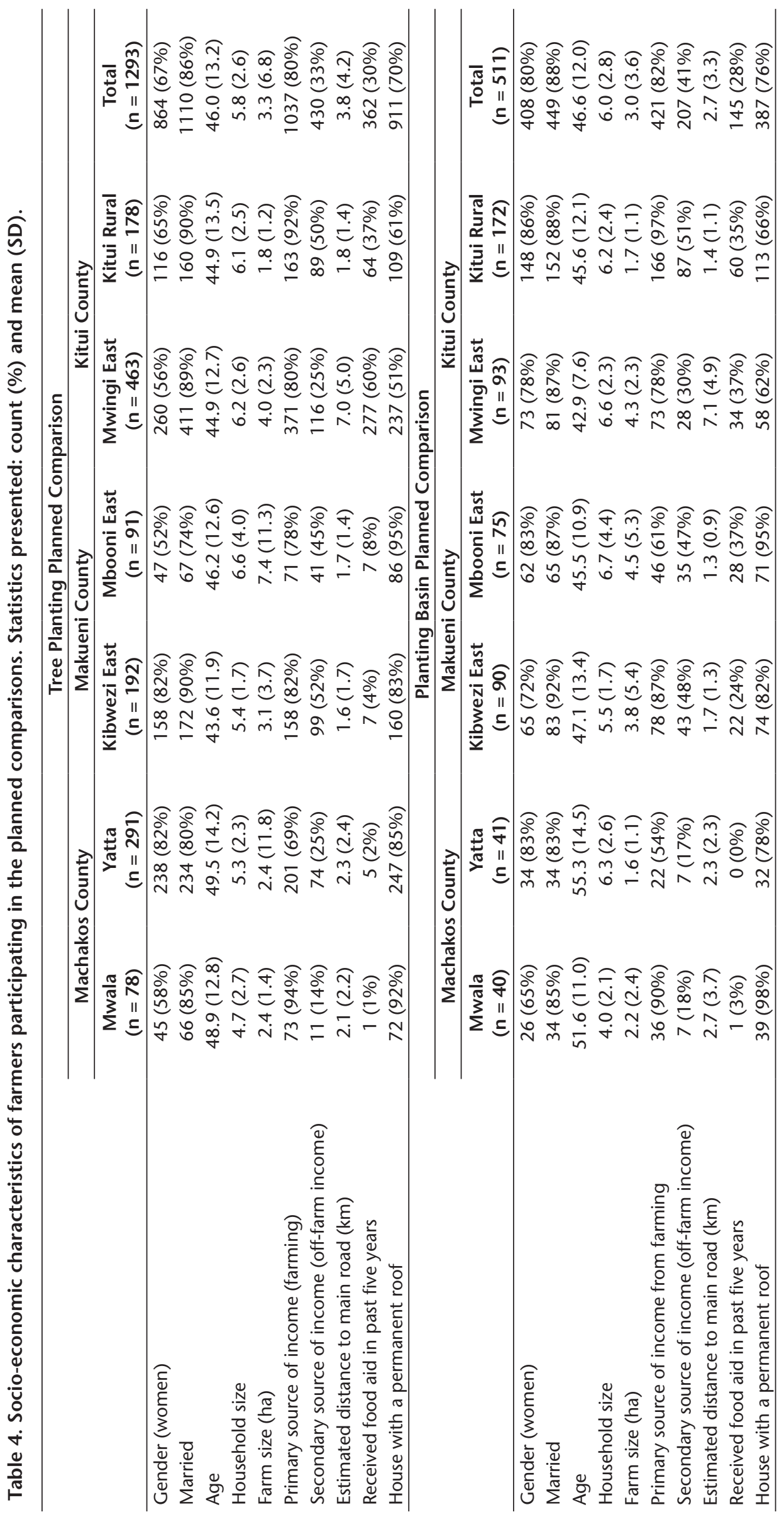


Table 5. Those involved in the household's decision to participate in the planned comparisons. Statistics presented: count (\%) and Fisher's exact test (two-sided). Unmarried includes single, divorced and widowed.

\begin{tabular}{|c|c|c|c|c|c|}
\hline & \multicolumn{4}{|c|}{ Who decided to be involved in the planned comparison? } & \multirow{2}{*}{$p$-value } \\
\hline & Myself & Jointly & Spouse & Other & \\
\hline \multicolumn{6}{|l|}{ Planting basins } \\
\hline Married women $(n=345)$ & $209(61 \%)$ & $125(36 \%)$ & $2(1 \%)$ & $9(3 \%)$ & \multirow{2}{*}{$<0.001$} \\
\hline Married men $(n=94)$ & $54(57 \%)$ & $30(32 \%)$ & $8(9 \%)$ & $2(2 \%)$ & \\
\hline Unmarried women $(n=44)$ & $43(98 \%)$ & $0(0 \%)$ & $0(0 \%)$ & $1(2 \%)$ & \multirow{2}{*}{-} \\
\hline Unmarried men $(n=3)$ & $3(100 \%)$ & $0(0 \%)$ & $0(0 \%)$ & $0(0 \%)$ & \\
\hline \multicolumn{6}{|l|}{ Tree planting } \\
\hline Married women $(n=758)$ & $521(69 \%)$ & $200(26 \%)$ & $23(3 \%)$ & $14(2 \%)$ & \multirow{2}{*}{$<0.001$} \\
\hline Married men $(n=382)$ & $322(84 \%)$ & $48(13 \%)$ & $6(2 \%)$ & $6(2 \%)$ & \\
\hline Unmarried women $(n=106)$ & $104(98 \%)$ & - & - & $2(2 \%)$ & \multirow{2}{*}{0.587} \\
\hline Unmarried men $(n=47)$ & $45(96 \%)$ & - & - & $2(4 \%)$ & \\
\hline \multicolumn{6}{|l|}{ Married women } \\
\hline Planting basins $(n=345)$ & $209(61 \%)$ & $125(36 \%)$ & $2(1 \%)$ & $9(3 \%)$ & \multirow{2}{*}{$<0.001$} \\
\hline Tree planting $(\mathrm{n}=758)$ & $521(69 \%)$ & $200(26 \%)$ & $23(3 \%)$ & $14(2 \%)$ & \\
\hline \multicolumn{6}{|l|}{ Married men } \\
\hline Planting basins $(n=94)$ & $54(57 \%)$ & $30(32 \%)$ & $8(9 \%)$ & $2(2 \%)$ & \multirow{2}{*}{$<0.001$} \\
\hline Tree planting $(n=382)$ & $322(84 \%)$ & $48(13 \%)$ & $6(2 \%)$ & $6(2 \%)$ & \\
\hline
\end{tabular}

report women's involvement in farming decisions (Deere and Twyman 2012, Anderson et al. 2017, Ambler et al. 2019). Unmarried respondents largely self-decided over the PCs, with no discernable differences with gender or practice.

\section{Intrahousehold Decision-Making Dynamics}

Although our survey suggested that uptake decisions were largely made individually, our FGDs revealed a more complex story and that, although initiated by individuals who attend agricultural workshops, acting on this decision often still involved some form of consultation between husband and wife. During the vignette exercise, over three-quarters of FGD participants indicated stories depicting some form of consultation as best-representing how men and women in their community take decisions (Table 6).

Asked why spouses usually consult over uptake decisions, both men and women explained that consultation helps avoid conflict within the household and that those who do not consult may miss out on valuable farming advice. Consultation was also used, particularly by men, to ensure household members felt included in a decision and would support an activity by providing their labor. For example, wives excluded from decisions over tree planting might be less likely to "protect the trees" or "help manage them". Similarly, women reported that if a man fails to consult their wife, "the project will not go forward because women are the tree caretakers", or that she may challenge his decision: "[the husband] doesn't want there to be conflict, so he consults his wife, otherwise she would ask 'why did you buy this species?!'”.

Unlike the vignettes representing women, FGDs were more divided over which of the vignettes depicting men were most representative. Although most men and women voted for the male vignette with the highest level of consultation, a substantial number voted for the vignette where the man alone decides to buy the trees but consults his wife on where to plant them. Some men explained that they prefer not to tell their wives that they are buying tree seedlings so their wives cannot disagree. One man asserted, "if the man asks whether to spend money on trees [his wife] would disagree with buying them and want to spend the money on other things. But if you go buy them, you have them and she cannot disagree", while others argued that as the household head and likely providing the capital, men decide whether or not to purchase trees, not their wives.

Referring to the vignette with the most votes, we asked participants what would happen should the couple disagree over which tree species to plant. Both men and women commonly explained that when couples disagree, they usually look to negotiate a compromise and would most likely decide to buy half of the trees based on the wife's preferences and the other half based on the husband's choice. One group of men even claimed that they would "go with the wife's idea because she is the one who takes care of management if the husband is not on the farm". Men and women emphasised that disagreements over farming activities are best avoided since they can lead to the division of household resources, delay time-sensitive activities such as planting, and even result in divorce. Nevertheless, asked what would happen should a disagreement persist, women reported that they would likely "stay silent" since their husband, as the household head, has the final say and must be respected.

Men and women reported that disagreements over uptake decisions are often due to only one household member attending workshops, most often the wife. In one group, men stated that "changing the mindset" of those who 
Table 6. Responses from focus group participants to male and female vignettes on the uptake of new technologies.

\begin{tabular}{|c|c|c|c|}
\hline \multicolumn{2}{|c|}{ Women's vignettes-attending a training on a new farming practice } & \multirow{2}{*}{$\begin{array}{l}\text { Men }(n=50) \\
76 \%(38)\end{array}$} & \multirow{2}{*}{$\begin{array}{c}\text { Women }(\mathbf{n}=66) \\
80 \%(53)\end{array}$} \\
\hline & $\begin{array}{l}\text { Faith talked to her husband and explained what she had learnt and } \\
\text { how it would benefit the farm. He then agreed on trying the new } \\
\text { practice and allowed her to make the decisions about it. }\end{array}$ & & \\
\hline Consultation & $\begin{array}{l}\text { Veronica also talked to her husband, but he was not convinced } \\
\text { because he did not attend the training. She insisted and after a long } \\
\text { discussion the husband finally agreed but he then set the conditions } \\
\text { for trying the new practice, like where on the farm and with which } \\
\text { crops. }\end{array}$ & $6 \%(3)$ & $11 \%(7)$ \\
\hline \multirow[t]{2}{*}{ No consultation } & $\begin{array}{l}\text { Margaret had to ask her husband for permission to apply her new } \\
\text { knowledge but he refused immediately without further discussion. } \\
\text { She could not try the new practice. }\end{array}$ & $12 \%(6)$ & $2 \%(1)$ \\
\hline & $\begin{array}{l}\text { Jane went straight to the field and started to try out what she learned. } \\
\text { She did not consult anyone. }\end{array}$ & $6 \%(3)$ & $8 \%(5)$ \\
\hline \multicolumn{2}{|c|}{ Men's vignettes-buying tree seedlings from the local nursery } & Men $(n=54)$ & Women $(n=66)$ \\
\hline \multirow[b]{2}{*}{ Consultation } & $\begin{array}{l}\text { Alex asked his wife what she thought about buying tree seedlings and } \\
\text { which species would be best for their farm and where to plant them. }\end{array}$ & $48 \%(26)$ & $42 \%(28)$ \\
\hline & $\begin{array}{l}\text { Peter decided to buy the seedlings on his own but asked his wife } \\
\text { about which species would be best for the farm and where to plant } \\
\text { them. }\end{array}$ & $33 \%(18)$ & $39 \%(26)$ \\
\hline \multirow[t]{2}{*}{ No consultation } & $\begin{array}{l}\text { James also decided to buy the seedlings on his own. He came home } \\
\text { and informed his wife about the seedlings and where he was going to } \\
\text { plant them. }\end{array}$ & $17 \%(9)$ & $15 \%(10)$ \\
\hline & $\begin{array}{l}\text { Sammy bought the tree seedlings on his own, came home and } \\
\text { planted them. He did not consult anyone. }\end{array}$ & $2 \%(1)$ & $3 \%(2)$ \\
\hline
\end{tabular}

do not attend a workshop can be challenging and that men are "resistant and reluctant to change when they have not seen [an innovation] work". Asked how such challenges might be overcome in the future, women proposed that a woman could ask their husbands to choose where on the farm to test the practice. This way, they could see if it worked before scaling to the rest of the farm. A similar solution, closely resembling the PC approach, was also proposed by one group of men: "they can try the [innovation] on one part of the farm and show the results to convince the one who did not attend. They can do one acre according to the man, one acre according to the woman, and then they see the results".

\section{Factors Influencing Women's Agency Over Decisions}

Our interviews and FGDs indicated that off-farm employment and outmigration of men influences women's agency over farming decisions. Asked how men and women within their household spend their time when they are not farming, $84 \%$ of interviewees reported that men are involved in off-farm income activities, many of whom were reported to work as casual labors in Nairobi or Mombasa. Conversely, only $31 \%$ of interviewees reported that women within their household had off-farm income. Several women interviewees reported that their husbands had given them full control over the day-to-day management of the farm in their absence. One woman explained, "I can call my spouse to discuss farming issues, but he might seem not to understand what I am saying. In such cases I make decisions such as what to plant on what plot, digging of the basins and also terraces". Women's FGDs also reported that women with husbands who work away tend to exercise greater agency in farming decisions: "if men are not around, women make the decisions about the [farm], if they are around then they consult their husbands". Yet, several women stressed that they must still consult their absent husbands over the phone.

Women's FGDs reported that their involvement in agricultural workshops had increased in recent years since men now "go where the money is". This had contributed to an increase in their influence over farming decisions, with women now more appreciated by their family members because of the knowledge that they gain from attending workshops. Asked how their families reacted the last time they tried an innovation, women recounted direct experiences associated with the basin $\mathrm{PC}$ where, once their husbands saw that the basins produced high yields, they had gained more freedom over decisions such as where to dig the basins and what to plant in them. In some cases, women reported being encouraged to try other innovations and receiving additional support from their family members, such as agricultural inputs, money for hiring labor, and assistance with digging the basins. 

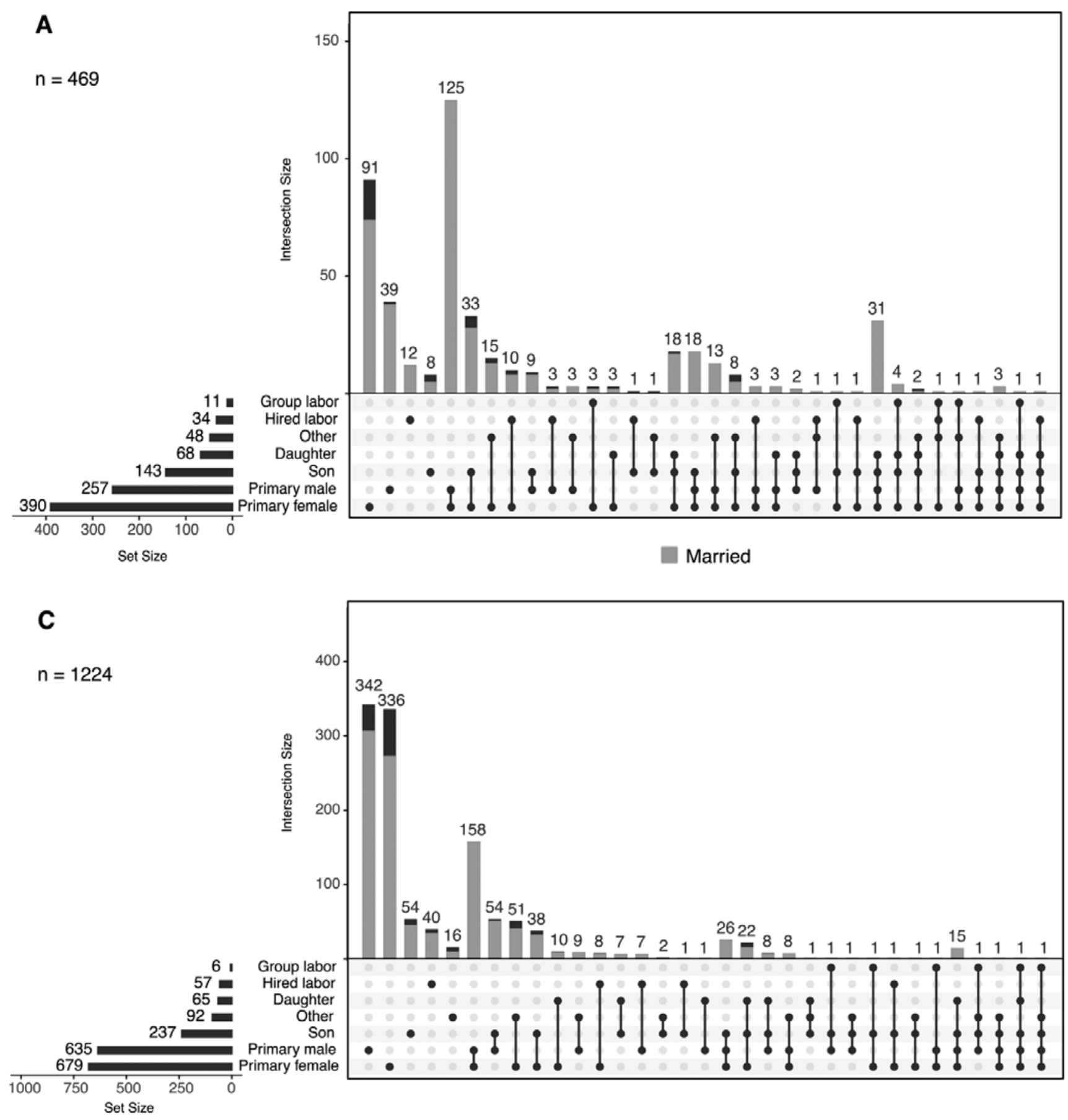

Figure 2. Upset plots of who was involved in A) digging the planned comparison planting basins, B) preparing land using farmers usual cultivation practice; C) planting the planned comparison tree seedlings, and D) watering the planned comparison tree seedlings. Upset plots employ a matrix-based layout to show intersections of sets and their frequencies (e.g., data from a multiple response question) (Conway et al. 2017). The bottom left bar chart shows the total number of respondents that selected each answer (set), the dot plot displays the various answer combinations (intersections), and the upper bar chart shows the number of respondents who answered using each combination (intersection size). 

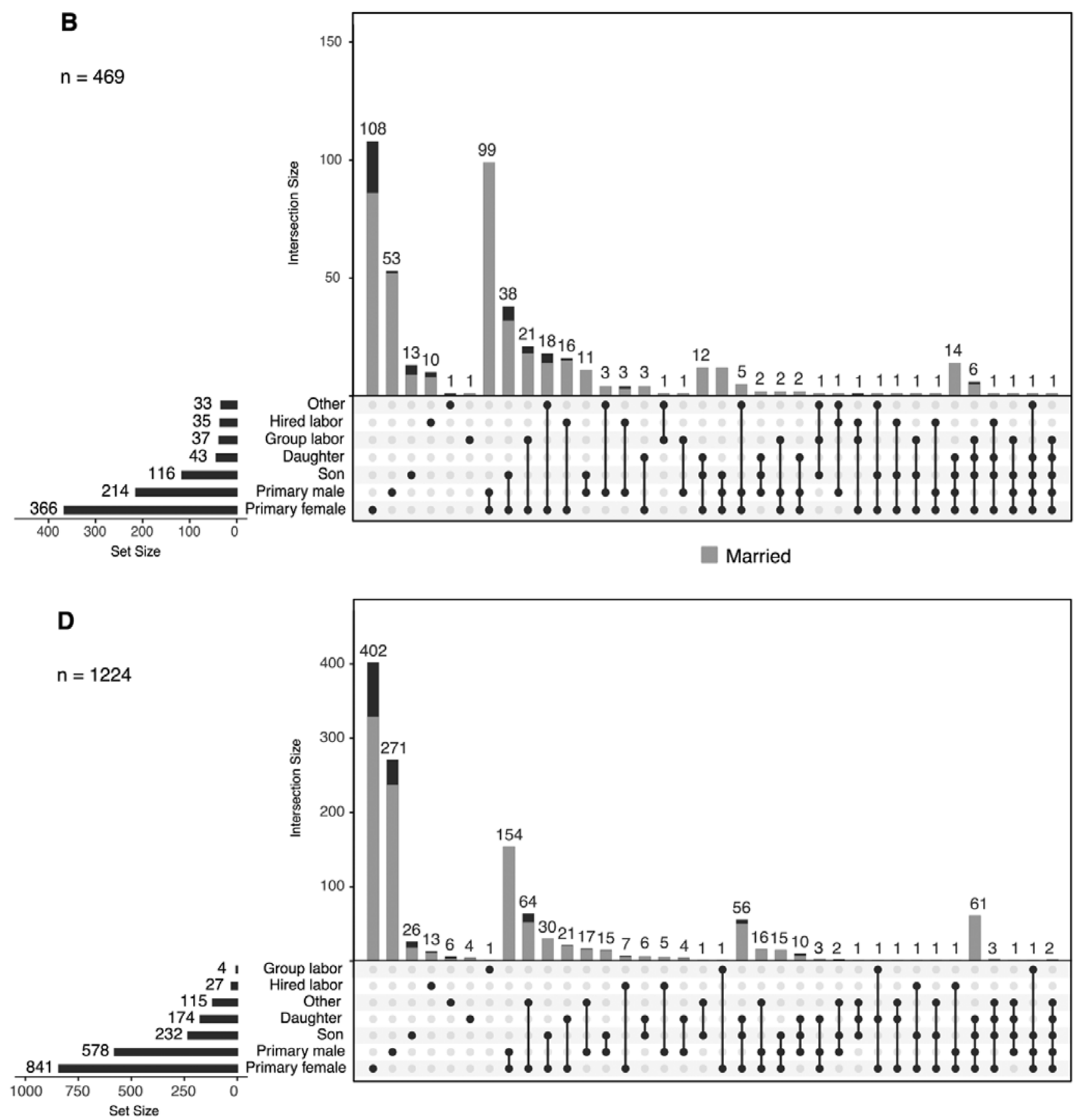

\section{Gendered Labor Patterns}

Our survey indicated that who was involved in implementing the PCs varied with restoration practice and respondent's gender and marital status (Figure 2 and Table 7). For married respondents, we saw a higher incidence of both male and female labor having been used to dig basins compared to planting trees, which was a more individual activity. Compared to married men, more women respondents reported that joint labor had been used to implement the PCs. Among married respondents, we also saw a higher incidence of joint labor for watering the trees than planting them, likely reflecting women's greater involvement in tree aftercare. For unmarried men and women, we saw a lower incidence of joint labor for both PCs.

Our survey also showed a higher incidence of femaleonly and male-only labor used to dig basins compared to farmers' usual cultivation practices (Figure 2 and Table 7). This was slightly more pronounced for female-only labor suggesting a shift from male to female labor with uptake of basins. Several women FGDs explained that using basins had increased the amount of farm work undertaken by women as, before taking up the basins, they had been less involved in land preparation activities. This trend varied 
Table 7. Gender of those involved in: digging the basins, planting and watering the trees, and preparing land using farmer's usual cultivation practice, grouped by survey respondents' gender and marital status. Statistics presented: count (\%) and Fisher's exact test (two-sided).

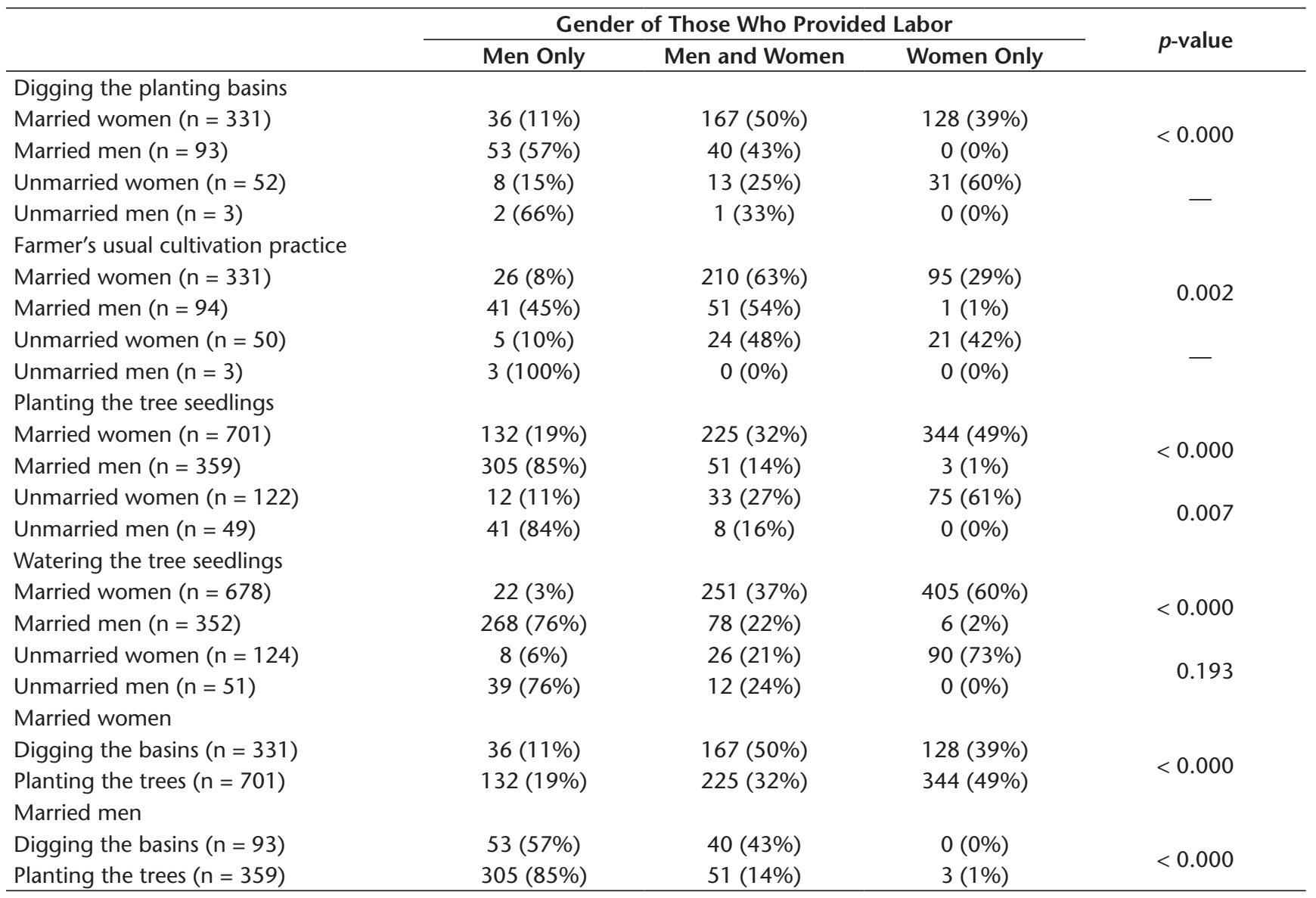

across sites (Figure 3). For example, men in Mwala were more involved in digging basins than men in other sites, reflecting that men in Mwala are likely more engaged in farming given the site's relative agricultural potential and market connectivity. Similarly, we saw the largest increase in women's participation in Kibwezi East and Yatta, sites associated with high male outmigration and off-farm employment.

\section{Trade-offs Between Workloads and Benefits}

Despite the majority of surveyed men and women reporting that using basins had increased the time taken to prepare the land for planting, a sizable proportion reported that using basins had reduced the overall amount of time they spend working on their farm (Table 8). FGDs and interviewees attributed this to basins requiring less weeding than their usual cultivation practices. FGDs also reported that using basins helps spread labor demand throughout the year since they can be dug throughout the dry season.

Although digging basins takes more time than other cultivation practices, both men and women FGDs reported that basins are more productive because of their ability to capture run-off, control erosion and increase soil fertility, and worth the additional time investment, especially when rainfall is limited. Furthermore, women argued that digging basins did not affect their ability to perform other responsibilities since they set aside time to dig them and had formed labor exchange groups to help each other dig the basins (as reflected in Figure 2 by the higher incidence of "group labor" for digging basins).

While the project trees were still young and not yet producing, the main expected benefit and reason for interviewees choosing to plant the tree seedlings was income from fruit and timber sales, followed by increased soil fertility through leaf decomposition and reduced soil erosion. Unlike the basins, the vast majority of survey respondents reported that the tree planting PC had increased the amount of time they spend working on their farm (Table 8). Nevertheless, most interviewees reported that since tree planting was a one-day activity with limited follow-up, their involvement in the PC had not impacted their ability to perform other activities. The majority of survey respondents, regardless of gender and marital status, reported that over the next 12 months they planned to dig more basins and plant more trees on their farm (Table 9). Reasons for not digging more basins or planting more trees centred on labor and financial constraints, respectively (Table 10). 

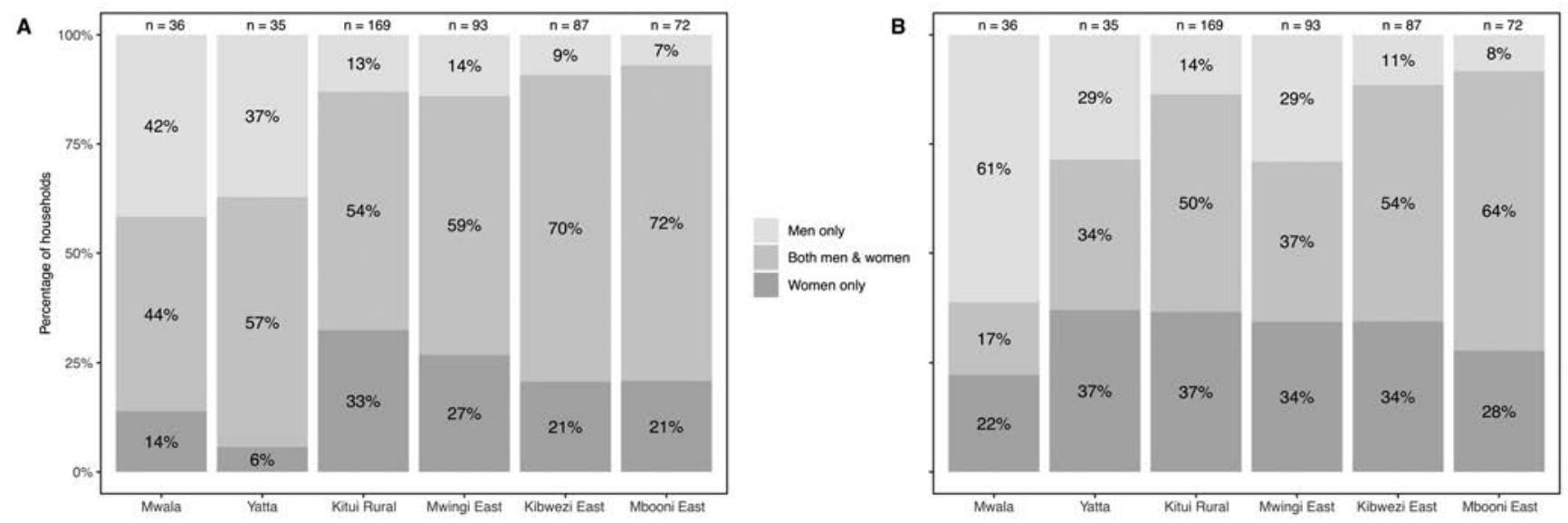

Figure 3. Gender of those involved in A) digging the planned comparison planting basins, and B) preparing land using farmer's usual cultivation practice, in each study site.

\section{Implications and Recommendations}

Three key insights emerge from our study. First, in married households the uptake of restorative farming practices is generally not a unitary decision made by individuals acting alone, but involves some form of consultation between husband and wife. Secondly, multiple social dimensions intersect to shape men's and women's interest in, contributions to, and benefit from different restoration practices. These include the gender-related roles and norms surrounding the use and control of household resources and outputs from innovations, and vary with local socio-economic context. Finally, the intrahousehold dynamics that underpin adoption processes are shaped by women's increasing involvement in innovation processes and broader societal changes, particularly the outmigration of rural men. In the following section, we discuss these three insights and their implications for scaling-up on-farm restoration in eastern Kenya and set out several recommendations for more inclusive and gender-responsive restoration efforts.

Table 8. Reported impact of being involved in the tree planting and planting basin planned comparisons on survey respondent's time spent preparing land for planting and their overall amount of time spent working on their farm. Statistics presented: count (\%) and Fisher's exact test (two-sided).

\begin{tabular}{|c|c|c|c|c|}
\hline & Increased & Decreased & Same & $p$-value \\
\hline \multicolumn{5}{|c|}{ Impact of basins on time spent preparing land } \\
\hline Married women $(n=345)$ & $268(78 \%)$ & $58(17 \%)$ & $19(6 \%)$ & \multirow{2}{*}{0.302} \\
\hline Married men $(n=94)$ & $68(72 \%)$ & $17(18 \%)$ & $9(10 \%)$ & \\
\hline Unmarried women $(n=44)$ & $37(84 \%)$ & $2(5 \%)$ & $5(11 \%)$ & \multirow{2}{*}{ - } \\
\hline Unmarried men $(n=3)$ & $1(33 \%)$ & $2(66 \%)$ & $0(0 \%)$ & \\
\hline \multicolumn{5}{|c|}{ Impact of basins on overall time on farm } \\
\hline Married women $(n=345)$ & $195(57 \%)$ & $130(38 \%)$ & $20(6 \%)$ & \multirow{2}{*}{0.050} \\
\hline Married men $(n=94)$ & $55(59 \%)$ & $28(30 \%)$ & $11(12 \%)$ & \\
\hline Unmarried women $(n=44)$ & $24(55 \%)$ & $13(30 \%)$ & $7(16 \%)$ & \multirow{2}{*}{-} \\
\hline Unmarried men $(n=3)$ & $1(33 \%)$ & $1(33 \%)$ & $1(33 \%)$ & \\
\hline \multicolumn{5}{|c|}{ Impact of trees on overall time on farm } \\
\hline Married women $(n=758)$ & $501(66 \%)$ & $49(7 \%)$ & $208(27 \%)$ & \multirow{2}{*}{$<0.000$} \\
\hline Married men $(n=382)$ & $300(79 \%)$ & $19(5 \%)$ & $63(16 \%)$ & \\
\hline Unmarried women $(n=106)$ & $70(66 \%)$ & $6(6 \%)$ & $30(28 \%)$ & \multirow{2}{*}{0.427} \\
\hline Unmarried men $(n=47)$ & $36(77 \%)$ & $1(2 \%)$ & $10(21 \%)$ & \\
\hline \multicolumn{5}{|c|}{ Impact on overall time on farm: married women } \\
\hline Planting basins $(\mathrm{n}=345)$ & $195(57 \%)$ & $130(38 \%)$ & $20(6 \%)$ & \multirow{2}{*}{$<0.000$} \\
\hline Tree planting $(\mathrm{n}=758)$ & $501(66 \%)$ & $49(7 \%)$ & $208(27 \%)$ & \\
\hline \multicolumn{5}{|c|}{ Impact on overall time on farm: unmarried women } \\
\hline Planting basins $(n=44)$ & $24(55 \%)$ & $13(30 \%)$ & $7(16 \%)$ & \multirow{2}{*}{$<0.000$} \\
\hline Tree planting $(n=106)$ & $70(66 \%)$ & $6(6 \%)$ & $30(28 \%)$ & \\
\hline \multicolumn{5}{|c|}{ Impact on overall time on farm: married men } \\
\hline Planting basins $(\mathrm{n}=94)$ & $55(59 \%)$ & $28(30 \%)$ & $11(12 \%)$ & \multirow{2}{*}{$<0.000$} \\
\hline Tree planting $(n=382)$ & $300(79 \%)$ & $19(5 \%)$ & $63(16 \%)$ & \\
\hline
\end{tabular}


Table 9. Whether survey respondents planned to dig more basins or plant more trees in the next 12 months. Statistics presented: count (\%) and Fisher's exact test (two-sided).

\begin{tabular}{lcc}
\hline & Yes & $p$-value \\
\hline Do you plan to dig more planting basins next season? & & 0.856 \\
Married women $(\mathrm{n}=345)$ & $304(88 \%)$ & - \\
Married men $(\mathrm{n}=94)$ & $84(89 \%)$ & $37(84 \%)$ \\
Unmarried women $(\mathrm{n}=44)$ & $1(33 \%)$ & \\
Unmarried men $(\mathrm{n}=3)$ & $571(75 \%)$ & 0.770 \\
Do you plan to plant more trees next season? & $291(76 \%)$ \\
Married women $(\mathrm{n}=758)$ & $83(78 \%)$ & 0.677 \\
Married men $(\mathrm{n}=382)$ & $35(74 \%)$ & \\
Unmarried women $(\mathrm{n}=106)$ & \\
Unmarried men $(\mathrm{n}=47)$ & & \\
\hline
\end{tabular}

\section{Intrahousehold Approaches to On-farm Restoration}

Based on our findings, we argue that in the eastern drylands of Kenya, employing an intrahousehold approach to restoration is likely to increase both the uptake of restoration practices and the success and equity of on-farm restoration efforts. A common assumption in agricultural development is that the household head, often a man, is the primary decision-maker over farming-related activities. Our study challenges this notion and illustrates that, at least in eastern Kenya, decisions over the uptake of restorative farming practices are often initiated by women and usually involve some form of consultation between husband and wife. These findings further contribute to growing evidence that households in SSA often employ different decision-making dynamics with varying degrees of consultation, and that the household head is not always the sole decision-maker (Doss and Meinzen-Dick 2015, Meijer et al. 2015, Doss and Quisumbing 2020).

Assumptions about who is involved in uptake decisions are likely to have important implications for the uptake of on-farm restoration efforts. Although our study only included those who had implemented the PCs, our findings indicate that the uptake of restoration practices may be constrained by the fact that only one household member usually attends training workshops, and that women can find it challenging to persuade their husbands of the potential benefits from an innovation. Restoration projects engaging only one household member without considering the whole household and all of those involved in uptake decisions may be constraining greater uptake of restoration practices. Consequently, we recommend that initiatives aiming to restore degraded farmlands identify clearly who within the household is involved in uptake decisions. Furthermore, while our surveys and interviews included only one member from each household, recent studies indicate that interviewing both spouses within a household can provide a richer and more nuanced understanding of intrahousehold decision-making dynamics (Acosta et al. 2019, Ambler et al. 2019, Bernard et al. 2020).
Who is involved in uptake decisions is also likely to influence the success and sustainability of restoration efforts. For instance, several studies indicate that joint decision-making between husband and wife over tree planting is associated with higher densities of on-farm trees than when decisions are made alone (Wanyoike 2001, Meijer et al. 2015). As argued by Kiptot and Franzel (2012) and supported by our findings, this is likely partially explained by both husband and wife on jointly managed farms providing labor for tree establishment. Similar to Shibata et al. (2020), we found that men's and women's involvement in uptake decisions was strongly related to their labor contributions in implementing and managing an innovation. In our study, consultation was seen, especially by men, as a means of assuring buy-in from other household members and securing the success of an innovation, as illustrated by spousal consultation being perceived as critical for successful tree establishment since women are heavily involved in caring for young trees.

Men's and women's participation in implementing an innovation is also likely to influence their authority over the resulting outputs (e.g., crops and income), and therefore the distribution of benefits from on-farm restoration efforts (Shibata et al. 2020). To increase both the uptake of practices and the success and equity of on-farm restoration efforts, we recommend that initiatives employ an intrahousehold approach, and look to encourage joint decision-making and couple attendance at workshops and, in situations when couple attendance is not possible, provide women with additional training in negotiation skills. Furthermore, the PC approach was proposed by study participants as a potential mechanism for negotiating the trial of an innovation. Encouraging on-farm experimentation could therefore provide a potential pathway to engaging the wider household in on-farm restoration activities and increasing uptake.

\section{Gendered Interests, Contributions and Benefits from Restoration}

We recommend that initiatives seek to understand the gender roles and relations that underpin different groups of men's and women's access and control of household 
Table 10. Ten most frequently used words by survey respondents when explaining why they did not intend to dig more planting basins $(n=60)$ or plant more trees $(n=316)$.

\begin{tabular}{lclc}
\hline & Tree Planting & \multicolumn{2}{c}{ Planting Basins } \\
\hline Word & Frequency & Word & Frequency \\
\hline Lack & 103 & Labor & 19 \\
Money & 78 & Intensive & 11 \\
Water & 68 & Time & 11 \\
Maintain & 48 & Season & 8 \\
Purchase & 46 & Consuming & 6 \\
Capital & 43 & Dig & 6 \\
Lacks & 40 & Man & 6 \\
Seedlings & 31 & Power & 6 \\
Buy & 28 & Tedious & 6 \\
Funds & 28 & Lack & 5 \\
\hline
\end{tabular}

resources, and their interest in, contribution to, and benefit from different restoration practices. In our study, men's and women's authority over uptake decisions were shaped by gender norms surrounding the use and control of resources and outputs from restoration practices. For instance, women's greater interest and authority over the basin PC likely reflects that basins are associated with growing food for the family, a domain generally seen as a woman's responsibility. Similarly, men's greater interest and self-decision over the tree planting PC likely reflects customary norms surrounding land and tree tenure (Kiptot and Franzel 2012).

In SSA, men typically have greater authority over land and agricultural enterprises that generate high revenues (Njuki et al. 2011). This includes agroforestry enterprises involving high-value products (Kiptot and Franzel 2012). Although the project trees were still young and not yet producing, most seedlings planted were of species with high commercial value for fruit or timber, potentially further explaining men's greater interest and involvement in the tree planting PC compared to the basin PC. Given that men's and women's rights over land and trees shape their incentives to plant trees and invest in land-based measures (Meinzen-Dick 2006, Mukadasi and Nabalegwa 2007, Lovo 2016), it is essential that restoration initiatives identify the key gender-tenure interactions within a locality, and how these relate to the uptake of different innovations, the distribution of benefits within the household, and genderequitable outcomes.

Our study also reveals that intrahousehold decisionmaking and labor dynamics vary with marital status and male absence associated with off-farm employment and outmigration. These findings contribute to a growing awareness that multiple social dimensions intersect with gender to shape men's and women's interest in, contribution to, and benefit from agricultural innovations (Carr and Thompson 2014), including age and position in household (Crossland et al. 2021, LaRue et al. 2021), wealth (Shibata et al. 2020), and kinship structures (Meijer et al. 2015).
Understanding these social dimensions begins with conducting gender analysis of restorative farming practices. For instance, initiatives could look to integrate tools from existing assessment methodologies into project activities, for example, tools from the INGENAES toolkit (Manfre et al. 2017), GENNOVATE methodology (Petesch et al. 2018), or other gender-transformative approaches (FAO et al. 2020).

Furthermore, similar to other studies (Baudron et al. 2007, Nyanga et al. 2012), we found evidence that using basins can alter when associated farming activities occur (i.e., land preparation), how long they take (i.e., weeding) and who is involved. Despite a potential increase in their labor burden, women perceived digging basins to be worthwhile. These findings highlight the importance of understanding how restoration efforts influence the men's and women's workloads, but also how farmers perceive and value their time and benefits from these practices (Njuki et al. 2014, Theis et al. 2018). While quantitative approaches to cost-benefit analysis might conclude that the time spent digging basins is not worthwhile, farmers, especially women, may value costs and benefits differently and perceive that the benefits outweigh the labor requirement. We recommend that initiatives conduct gender analysis of innovations not only during their design but also following their uptake, and include the views and perceptions of project beneficiaries when assessing the costs and benefits from restoration activities.

\section{Changes in the Wider Social Context of On-farm Restoration}

As our study demonstrates, the intrahousehold roles and relations underpinning adoption processes are, in turn, shaped by women's increasing involvement in agricultural innovation and broader societal changes, particularly the outmigration of rural men. In line with a growing literature (Chant and Radcliffe 1992, Yabiku et al. 2010, Saha et al. 2018), our findings show that women with migrant husbands often have greater agency over farming decisions than women with resident husbands. Furthermore, we found that women are heavily involved in uptake decisions, including those regarding tree planting, and that even women with resident husbands may be able to contest restoration decisions. These findings challenge the narrative that men in eastern Kenya are the chief decision-makers over farming and tree planting (Muok et al. 1998, Kiptot et al. 2014), and likely reflect women's increased participation in agricultural workshops and farm management in the absence of their male relatives (Crossland et al. 2021). Similar to other studies, our findings indicate that when women attend agricultural workshops and are allowed to implement their knowledge, they gain more confidence and recognition that can lead to greater agency in farming decisions (Nyasimi and Huyer 2017, Bullock and Tegbaru 2019). 
Nevertheless, while women may be gaining agency over farming decisions, there is rising concern that male outmigration may result in negative consequences for women's welfare (Saha et al. 2018). For instance, the absence of male members during peak farming periods may increase agricultural workloads for women and reduce time available for household tasks and child care (Slavchevska et al. 2016). Given that on-farm restoration efforts are often labor-intensive, their promotion in regions experiencing increasing male outmigration risks placing the burden of restoration disproportionally on women. While beyond the scope of this study, the impact of male outmigration on the capacity of rural households to restore degraded lands is a pressing issue for future research.

Our findings also illustrate that, if on-farm restoration efforts are to meet both social and ecological objectives, deliberate actions may be needed to further shift gender relations in a direction that increases women's agency in respect of farming decisions. Despite women's increased involvement in workshops and uptake decisions, it is evident that asymmetries in decision-making authority persist. Women's ability to implement innovations across the farm largely depended on some form of pro forma consultation with their husbands and even women with absent husbands were often still obligated to consult their spouse. These findings are similar to other studies in SSA, including those conducted elsewhere in Kenya (Acosta et al. 2019, Bullock and Tegbaru 2019, Shibata et al. 2020). It is also worth noting that most women involved in our study were older, married, and had access to land. Our results likely overlook considerable variation in the experiences of different groups of women, with older women likely better able to negotiate access to land, influence decisions and have more free time to attend agricultural workshops than younger women (Rietveld 2017).

While women's participation in agricultural workshops alone is unlikely to transform entrenched gender norms, integrating deliberate actions to address inequitable gender relations in project design and implementation, show promise (Kantor et al. 2015, Cole et al. 2020, Lecoutere and Wuyts 2020). For instance, in Uganda a research project employing participatory approaches that aimed to address gender inequalities, resolve conflict, and foster collaboration and negotiation is reported to have achieved substantial gains in strengthening women's rights to forest and tree resources and their inclusion in community forestry decisions (Mukasa et al. 2016). Through integrating gender-transformative approaches and using project activities to facilitate critical awareness and discussion of gender-inequitable relations, we argue that initiatives could not only overcome gender-based constraints to scaling-up on-farm restoration efforts, but provide a platform for social learning and the transformation of inequitable gender relations within households and the wider community.

\section{Conclusion}

In this study, we demonstrate that successful restoration activity in the eastern drylands of Kenya will only be achieved with careful consideration of how gender dimensions feed into decision-making. This requires understanding the intrahousehold dynamics surrounding innovation uptake and the distribution of resulting benefits. We argue that employing an intrahousehold approach to restoration is likely to increase both the uptake of practices and the success and equity of on-farm restoration efforts. We recommend that restoration initiatives seek to understand the gender roles and relations that underpin different groups of men's and women's access to and control of household resources, and their interest in, contribution to, and benefits from different innovations. Our findings illustrate the importance of understanding intrahousehold decision-making patterns and that, if on-farm restoration efforts are to meet both social and ecological objectives, deliberate actions may be needed to shift gender relations in a direction where women have increased voice over farming decisions.

\section{Acknowledgments}

This research was funded by the International Fund for Agricultural Development (IFAD) and European Commission through the project "Restoration of degraded lands for food security and poverty reduction in East Africa and the Sahel: taking successes to scale", grant numbers: 2000000520 and 2000000976 and the CGIAR Research Programme on Forests, Trees and Agroforestry (FTA). We thank the women and men who participated in this research for sharing their time and insights, and gratefully acknowledge the support of the enumerators and community facilitators, including Stephen Maithya, Caroline Mbuvi, Sylvester Muendo, Silas Muthuri, Francisca Mutua and Mercy Mwea. We would also like to thank Marlène Elias, Ruth Meinzen-Dick and two anonymous reviewers for their valuable comments on earlier drafts of the manuscript.

\section{References}

Acosta, M., M. van Wessel, S. van Bommel, E.L. Ampaire, J. Twyman, L. Jassogne et al. 2019. What does it mean to make a 'joint' decision? Unpacking intra-household decision making in agriculture: Implications for policy and practice. Journal of Development Studies 56:1-20.

Ambler, K., C. Doss, C. Kieran and S. Passarelli. 2019. He says, she says: Spousal disagreement in survey measures of bargaining power. Economic Development and Cultural Change doi:10.1086/703082.

Anderson, C.L., T.W. Reynolds and M.K. Gugerty. 2017. Husband and wife perspectives on farm household decision-making authority and evidence on intra-household accord in rural Tanzania. World Development 90:169-183.

Badstue, L., A. Van Eerdewijk, K. Danielsen, M. Hailemariam and E. Mukewa. 2020. How local gender norms and intra-household dynamics shape women's demand for labour-saving technologies: Insights from maize-based livelihoods in Ethiopia and Kenya. 
Gender, Technology and Development doi:10.1080/09718524. 2020.1830339.

Baudron, F., H.M. Mwanza, B. Triomphe and M. Bwalya. 2007. Conservation agriculture in Zambia: A case study of Southern Province. African Conservation Tillage Network, Centre de Coopération Internationale de Recherche Agronomique pour le Dévelopment. Rome: Food and Agricultural Organization of the United Nations.

Bernard, T., C. Doss, M. Hidrobo, J. Hoel and C. Kieran. 2020. Ask me why: Patterns of intrahousehold decision-making. World Development doi:10.1016/j.worlddev.2019.104671.

Brancalion, P.H.S., A. Niamir, E. Broadbent, R. Crouzeilles, F.S.M. Barros, A.M. Almeyda Zambrano et al. 2019. Global restoration opportunities in tropical rainforest landscapes. Science Advances 5:1-11.

Bullock, R. and A. Tegbaru. 2019. Women's agency in changing contexts: A case study of innovation processes in Western Kenya. Geoforum 105:78-88.

Carr, E.R. and M.C. Thompson. 2014. Gender and climate change adaptation in agrarian settings: Current thinking, new directions, and research frontiers. Geography Compass 8:182-197.

Chant, S. and S.A. Radcliffe. 1992. Migration and development: The importance of gender. Pages 1-29 in S. Chant (eds), Gender and Migration in Developing Countries. London: Belhaven Press.

Coe, R., K. Hughes, P. Sola and F. Sinclair. 2017. Planned comparisons demystified. ICRAF Working Paper No 263. Nairobi, Kenya: World Agroforestry Centre.

Coe, R., F. Sinclair and E. Barrios. 2014. Scaling up agroforestry requires research "in" rather than "for" development. Current Opinion in Environmental Sustainability 6:73-77.

Cole, S.M., A.M. Kaminski, C. McDougall, A.S. Kefi, P.A. Marinda, M. Maliko et al. 2020. Gender accommodative versus transformative approaches: A comparative assessment within a postharvest fish loss reduction intervention. Gender, Technology and Development 24:48-65.

Conway, J.R., A. Lex and N. Gehlenborg. 2017. UpSetR: An R package for the visualization of intersecting sets and their properties. Bioinformatics 33:2938-2940.

Cowie, A.L., B.J. Orr, V.M. Castillo Sanchez, P. Chasek, N.D. Crossman, A. Erlewein et al. 2018. Land in balance: The scientific conceptual framework for land degradation neutrality. Environmental Science and Policy 79:25-35.

Crossland, M., A.M. Paez Valencia, T. Pagella, K. Mausch, D. Harris, L. Dilley et al. 2021. Women's changing opportunities and aspirations amid male outmigration: Insights from Makueni County, Kenya. The European Journal of Development Research doi:10.1057/s41287-021-00362-8.

Danjuma, M.N. and S. Mohammed. 2015. Zai pits system: A catalyst for restoration in the drylands. IOSR Journal of Agriculture and Veterinary Science (IOSR-JAVS) 8:01-04.

Deere, C.D. and C.R. Doss. 2006. The gender asset gap: What do we know and why does it matter? Feminist Economics 12:1-50.

Deere, C.D. and J. Twyman. 2012. Asset ownership and egalitarian decision making in dual-headed households in Ecuador. Review of Radical Political Economics 44:313-320.

Derero, A., R. Coe, C. Muthuri, K.M. Hadgu and F. Sinclair. 2020. Farmer-led approaches to increasing tree diversity in fields and farmed landscapes in Ethiopia. Agroforestry Systems doi:10.1007/ s10457-020-00520-7.

Doss, C.R. 2013. Intrahousehold bargaining and resource allocation in developing countries. World Bank Research Observer 28:52-78.
Doss, C.R. 2001. Designing agricultural technology for African women farmers: Lessons from 25 years of experience. World Development 29:2075-2092.

Doss, C.R. and R. Meinzen-Dick. 2015. Collective action within the household: Insights from natural resource management. World Development 74:171-183.

Doss, C.R. and M.L. Morris. 2001. How does gender affect the adoption of agricultural innovations?: The case of improved maize technology in Ghana. Agricultural Economics 25:27-39.

Doss, C.R. and A.R. Quisumbing. 2020. Understanding rural household behavior: Beyond Boserup and Becker. Agricultural Economics 51:47-58.

Farnworth, C.R., T. Jafry, P. Bharati, L. Badstue and A. Yadav. 2020. From working in the fields to taking control: Towards a typology of women's decision-making in wheat in India. European Journal of Development Research doi:10.1057/s41287-020-00281-0.

Food and Agriculture Organisation (FAO), International Fund for Agricultural Development and World Food Programme. 2020. Gender transformative approaches for food security, improved nutrition and sustainable agriculture-A compendium of fifteen good practices. Rome: Food and Agricultural Organization of the United Nations.

Funk, C., P. Peterson, M. Landsfeld, D. Pedreros, J. Verdin, S. Shukla et al. 2015. The climate hazards infrared precipitation with stations-A new environmental record for monitoring extremes. Scientific Data 2:1-21.

Gitau, A.N., L.O. Gumbe and E.K. Biamah. 2006. Influence of soil water on stress-strain behaviour of a compacting soil in semiarid Kenya. Soil and Tillage Research 89:144-154.

Glover, D., J. Sumberg, G. Ton, J. Andersson and L. Badstue. 2019. Rethinking technological change in smallholder agriculture. Outlook on Agriculture 48:169-180.

Haider, H., M. Smale and V. Theriault. 2018. Intensification and intrahousehold decisions: Fertilizer adoption in Burkina Faso. World Development 105:310-320.

Hartung, C., Y. Anokwa, W. Brunette, A. Lerer, C. Tseng and G. Borriello. 2010. Open Data Kit: Tools to build information services for developing regions. Pages 1-12 in Proceedings of the 4th ACM/IEEE International Conference on Information and Communication Technologies and Development. New York, NY: Association for Computing Machinery.

Kabeer, N. 1999. Resources, agency, achievements: reflections on the measurement of women's empowerment. Development and Change 30:435-64.

Kantor, P., M. Morgan and A. Choudhury. 2015. Amplifying outcomes by addressing inequality: The role of gender-transformative approaches in agricultural research for development. Gender, Technology and Development 19:292-319.

Kenya Food Security Steering Group (KFSSG). 2019. The long rains season assessment report. Nairobi, Kenya: Republic of Kenya.

Kenya National Bureau of Statistics (KNBS). 2019. Kenya population and housing census 2019. Volume IV: Distribution of Population by Socio-Economic Characteristics. Nairobi: Republic of Kenya.

Kiptot, E. and S. Franzel. 2012. Gender and agroforestry in Africa: A review of women's participation. Agroforestry Systems 84:35-58.

Kiptot, E., S. Franzel and A. Degrande. 2014. Gender, agroforestry and food security in Africa. Current Opinion in Environmental Sustainability 6:104-109.

LaRue, K., T. Daum, K. Mausch and D. Harris. 2021. Who wants to farm? Answers depend on how you ask: A case study on youth aspirations in Kenya. The European Journal of Development Research doi:10.1057/s41287-020-00352-2. 
Lecoutere, E. and E. Wuyts. 2020. Confronting the wall of patriarchy: Does participatory intrahousehold decision making empower women in agricultural households? Journal of Development Studies doi:10.1080/00220388.2020.1849620.

De Leeuw, J., M. Njenga, B. Wagner and M. Iiyama. 2014. Treesilience: An assessment of the resilience provided by trees in the drylands of Eastern Africa. Nairobi: World Agroforestry Centre.

Lohbeck, M., P. Albers, L.E. Boels, F. Bongers, S. Morel, F. Sinclair et al. 2020. Drivers of farmer-managed natural regeneration in the Sahel. Lessons for restoration. Scientific Reports 10:1-11.

Lovo, S. 2016. Tenure insecurity and investment in soil conservation. Evidence from Malawi. World Development 78:219-229.

Magaju, C., L.A. Winowiecki, M. Crossland, A. Frija, H. Ouerghemmi, N. Hagazi et al. 2020. Assessing context-specific factors to increase tree survival for scaling ecosystem restoration efforts in East Africa. Land 9:1-20.

Magruder, J.R. 2018. An assessment of experimental evidence on agricultural technology adoption in developing countries. Annual Review of Resource Economics 10:299-316.

Manfre, C., D. Rubin and C. Nordehn. 2017. Assessing how agricultural technologies can change gender dynamics and food security: Part three. Washington DC: United States Agency for International Development.

Mazvimavi, K. and S. Twomlow. 2009. Socioeconomic and institutional factors influencing adoption of conservation farming by vulnerable households in Zimbabwe. Agricultural Systems 101:20-29.

Meijer, S.S., G.W. Sileshi, G. Kundhlande and D. Catacutan. 2015. The role of gender and kinship structure in household decisionmaking for agriculture and tree planting in Malawi. Journal of Gender, Agriculture and Food Security 1:54-76.

Meinzen-Dick, R. 2006. Women, land and trees. Pages 173-181 in D. Garrity, A. Okono, M. Grayson and S. Parrott (eds), World Agroforestry into the Future. Nairobi, Kenya: World Agroforestry Centre.

Meinzen-Dick, R., N. Johnson, A. Quisumbing, J. Njuki, J. Behrman, D. Rubin et al. 2011. Gender, assets, and agricultural development programs: A conceptual framework. CAPRi Working Paper No. 99. Washington, DC: International Food Policy Research Institute.

Meinzen-Dick, R., A. Quisumbing, J. Behrman, P. Biermayr-Jenzano, V. Wilde, M. Noordeloos et al. 2012. Engendering agricultural research, development, and extension. Washington, DC: International Food Policy Research Institute.

Ministry of Environment and Forestry (MEF). 2019. National strategy for achieving and maintaining over 10\% tree cover by 2022 . Nairobi: Ministry of Environment and Forestry, Republic of Kenya.

Minnemeyer, S., L. Laestadious, N. Sizer, S.L. Carole and P. Potapov. 2011. A world of opportunity-A world of opportunities for forest and landscape restoration. Washington, DC: World Resources Institute.

Mukadasi, B. and M. Nabalegwa. 2007. Gender mainstreaming and community participation in plant resource conservation in Buzaya county, Kamuli district, Uganda. African Journal of Ecology 45:7-12.

Mukasa, C., A. Tibazalika, E. Mwangi, A.Y. Banana, A. Bomuhangi and J. Bushoborozi. 2016. Strengthening women's tenure rights and participation in community forestry. Infobrief No.155. Bogor: Center for International Forestry Research.

Muli, M.B., D. Kengo, A. Mzingirwa and R. Musila. 2017. Performance of drought tolerant maize varieties under water harvesting technologies in the coastal region of Kenya. East African Agricultural and Forestry Journal 82:168-174.

Muok, B., J. Kamene, K. Kemmochi and A. Ali. 1998. Socio-economic and resource survey of Kitui district. Social forestry extension model development project. Kitui, Kenya: Kenya Forestry Research Institute.

Musangi, P. 2017. Women land and property rights in Kenya. Paper presented to the Annual World Bank Conference on Land and Poverty, Washington, DC, March 20-24.

Ndegwa, G., M. Iiyama, D. Anhuf, U. Nehren and S. Schlüter. 2017. Tree establishment and management on farms in the drylands: evaluation of different systems adopted by small-scale farmers in Mutomo District, Kenya. Agroforestry Systems 91:1043-1055.

Njuki, J., S. Kaaria, A. Chamunorwa and W. Chiuri. 2011. Linking smallholder farmers to markets, gender and intra-household dynamics: Does the choice of commodity matter? The European Journal of Development Research 23:426-443.

Njuki, J., J.R. Parkins and A. Kaler 2016. Transforming Gender and Food Security in the Global South. New York, NY: Routledge.

Njuki, J., E. Waithanji, B. Sakwa, J. Kariuki, E. Mukewa and J. Ngige. 2014. A qualitative assessment of gender and irrigation technology in Kenya and Tanzania. Gender, Technology and Development 18:303-340.

Nyanga, P.H., F.H. Johnsen and T.H. Kalinda. 2012. Gendered impacts of conservation agriculture and paradox of herbicide use among smallholder farmers. International Journal of Technology and Development Studies 3:1-24.

Nyasimi, M. and S. Huyer. 2017. Background: The gender gap in agriculture under a changing climate. Agriculture for Development 30:37-40.

Orwa, C., A. Mutua, R. Kindt, R. Jamnadass and A. Simons. 2009. Agroforestree Database: A tree reference and selection guide. Nairobi, Kenya: World Agroforestry Centre.

Petesch, P., R. Bullock, S. Feldman, L. Badstue, A. Rietveld, W. Bauchspies et al. 2018. Local normative climate shaping agency and agricultural livelihoods in sub-Saharan Africa. Journal of Gender, Agriculture and Food Security 3:108-130.

R Core Team. 2020. R. A language and environment for statistical computing. R Foundation for Statistical Computing, Vienna, Austria. www.R-project.org.

Ragasa, C., D. Sengupta, M. Osorio, N. Ourabahhaddad and K. Mathieson. 2014. Gender-specific approaches and rural institutions for improving access to and adoption of technological innovations. Rome, Italy: Food and Agriculture Organization.

Rietveld, A. 2017. Gender norms and agricultural innovation: Insights from Uganda. Pages 3-5 in K. Oborn, I., Vanlauwe, B., Phillips, M., Thomas, R., Brooijmans, W., Atta-krah (eds), Sustainable Intensification in Smallholder Agriculture: An Integrated Systems Research Approach. Oxfordshire, UK: Routledge.

Rockström, J., P. Kaumbutho, J. Mwalley, A.W. Nzabi, M. Temesgen, L. Mawenya et al. 2009. Conservation farming strategies in East and Southern Africa: Yields and rain water productivity from on-farm action research. Soil and Tillage Research 103:23-32.

Saha, S., R. Goswami and S.K. Paul. 2018. Recursive male out-migration and the consequences at source: A systematic review with special reference to the left-behind women. Space and Culture, India 5:30-53.

Secretariat of the Intergovernmental Science-Policy Platform on Biodiversity and Ecosystem Services (IPBES). 2018. The IPBES assessment report on land degradation and restoration. Bonn: Secretariat of the Intergovernmental Science-Policy Platform on Biodiversity and Ecosystem Services. 
Shibata, R., S. Cardey and P. Dorward. 2020. Gendered intra-household decision-making dynamics in agricultural innovation processes: Assets, norms and bargaining. Journal of International Development 32:1101-1125.

Sinclair, F. and R. Coe. 2019. The options by context approach: A paradigm shift in agronomy. Experimental Agriculture 55:1-13.

Slavchevska, V., S. Kaaria and S. Taivalmaa. 2016. Feminization of agriculture in the context of rural transformations: What is the evidence? Washington, DC: World Bank.

Sparks, A. 2018. Nasapower: A NASA POWER global meteorology, surface solar energy and climatology data client for R. Journal of Open Source Software 3:1035.

Theis, S., N. Lefore, R. Meinzen-Dick and E. Bryan. 2018. What happens after technology adoption? Gendered aspects of small-scale irrigation technologies in Ethiopia, Ghana, and Tanzania. Agriculture and Human Values 35:671-684.

Tiffen, M., M. Mortimore and F. Gichuki. 1994. More People, Less Erosion: Environmental Recovery in Kenya. Chichester, UK: John Wiley \& Sons.

Wanyoike, F. 2001. Dissemination and adoption of improved fodder trees: The case of Calliandra calothyrsus in Embu district, Kenya. MSc dissertation, University of Nairobi.

Winowiecki, L., C. Magaju, J. Nyaga, I. Ochenje, L. Wafula, M. Crossland et al. 2019. Farmer profiling data-Kenya. Nairobi: World Agroforestry Centre. hdl.handle.net/20.500.11766.1/FK2/ E4MRCZ.

World Agroforestry. 2020. Restoration of degraded land for food security and poverty reduction in East Africa and the Sahel: Taking successes in land restoration to scale. www.worldagro forestry.org/project/restoration-degraded-land-food-securityand-poverty-reduction-east-africa-and-sahel-taking.
Yabiku, S.T., V. Agadjanian and A. Sevoyan. 2010. Husbands' labor migration and wives' autonomy, Mozambique 2000-2006. Population Studies 64:293-306.

Mary Crossland (corresponding author) Bangor University, Bangor, Gwynedd, LL57 2DG, United Kingdom, Afp43d@ bangor.ac.uk.

Ana Maria Paez Valencia, World Agroforestry (ICRAF), Gigiri, Nairobi, Kenya.

Tim Pagella, Bangor University, Bangor, Gwynedd, United Kingdom.

Christine Magaju, World Agroforestry (ICRAF), Nairobi, Kenya.

Esther Kiura, World Agroforestry (ICRAF), United Nations Avenue, Nairobi, Kenya.

Leigh Winoweicki, Bangor University, Bangor, Gwynedd, United Kingdom.

Fergus Sinclair, Bangor University, Bangor, Gwynedd, United Kingdom and World Agroforestry (ICRAF), Gigiri, Nairobi, Kenya. 